\title{
Manajemen Krisis Dimasa Pandemi
}

\author{
Rully Afrita Harlianty ${ }^{\left.1^{*}\right)}$; Eka Nurzanah ${ }^{2}$; Sunarmi ${ }^{3}$; Nurhayati; Hamid Mukhlis ${ }^{5}$ \\ $\left.1^{*}\right), 4,5$ Program Studi Psikologi, Fakultas Sosial dan Bisnis Universitas Aisyah Pringsewu \\ 2,3Program Studi Akuntansi , Fakultas Sosial dan Bisnis Universitas Aisyah Pringsewu
}

e-mail: rullyafrita@aisyahuniversity.ac.id

\begin{abstract}
Abstrak. Coronavirus Disease 2019 (COVID-19) merupakan penyakit yang menyerang sistem pernafasan yang disebabkan oleh coronavirus. Sejak terjadinya wabah coronavirus pertama kali di Wuhan, China, COVID-19 telah menyebar hampir di seluruh dunia sehingga pada tanggal 11 Maret 2020 WHO (World Health Organization) menetapkan COVID-19 sebagai pandemik dengan total 114 negara terpapar COVID-19 (WHO, 2020). Indonesia telah dilaporkan sebanyak 51.427 kasus terkonfirmasi positif COVID-19 dengan 2.683 kasus kematian. pemerintah Indonesia berupaya menekan penyebaran infeksi COVID-19 dengan melakukan kebijakan Stay at Home. Karena hal tersebutlah, pandemik Covid-19 memunculkan berbagai permasalahan dalam domain kehidupan masyarakat seperti ekonomi (Laing, 2020). Pandemi COVID-19 menyebabkan perubahan kehidupan aktivitas masyarakat yang pada awalnya dapat beraktivitas bebas menjadi sangat terbatas sehingga menimbulkan permasalahan di masyarakat. Berdasarkan latar ini, tim dari Fakultas Sosial dan Bisnis Universitas Aisyah Pringsewu yang terdiri dari Program Studi Psikologi dan Program Studi Akuntasi melakukan kolaborasi dalam pengabdian kepada masyarakat mengenai "Manajemen Krisis di Masa Pandemi".
\end{abstract}

Kata kunci: Manajemen, Pandemi, Covid-19, Webinar

\section{Pendahuluan}

Coronavirus Disease 2019 (COVID-19) merupakan penyakit yang menyerang sistem pernafasan yang disebabkan oleh coronavirus. Sejak terjadinya wabah coronavirus pertama kali di Wuhan, China, COVID-19 telah menyebar hampir di seluruh dunia sehingga pada tanggal 11 Maret 2020 WHO (World Health Organization) menetapkan COVID-19 sebagai pandemik dengan total 114 negara terpapar COVID-19 (WHO, 2020). Berdasarkan data dari WHO (World Health Organization), pada 26 Juni 2020 dilaporkan sebanyak 9.472.473 kasus telah terkonfirmasi positif COVID-19 dalam skala global dengan laporan kematian sebanyak 484.236 kasus (WHO, 2020). Sedangkan di Indonesia telah dilaporkan sebanyak 51.427 kasus terkonfirmasi positif COVID-19 dengan 2.683 kasus kematian.

COVID-19 merupakan penyakit yang sangat menular sehingga pemerintah di berbagai negara telah melakukan kebijakan lock-down dan atau social distancing untuk mengurangi penyebaran infeksi virus antar manusia. Di Indonesia, pemerintah Indonesia berupaya menekan penyebaran infeksi COVID-19 dengan melakukan kebijakan Stay at Home. Karena hal tersebutlah, pandemik Covid-19 memunculkan berbagai permasalahan dalam domain kehidupan masyarakat seperti ekonomi (Laing, 2020), psikologis (Temsah et al., 2020), serta psikososial (Dubey et al., 2020). Pandemi COVID-19 menyebabkan perubahan kehidupan aktivitas masyarakat yang pada awalnya dapat beraktivitas bebas menjadi sangat terbatas sehingga menimbulkan permasalahan di masyarakat.

Sebuah penelitian yang melaporkan bahwa mayoritas individu merasa khawatir dengan permasalahan finansial selama "lockdown", mengalami gejala depresi dan merasa sulit untuk 
menyesuaikan diri dengan kondisi di masa pandemi (Kaustav \& Moumita, 2020). Beberapa kelompok masyarakat umumnya memiliki prevalensi tinggi mengalami gangguan psikologis, seperti depresi, kecemasan dan kualitas hidup yang buruk, yang dilatar belakangin oleh kebijakan "lockdown" yang dipaksakan oleh pemerintah dan hilangnya pendapatan selama terjadinya pandemi COVID-19 (Truman et al., 2009).

Berdasarkan latar belakang tersebut, tim dari Fakultas Sosial dan Bisnis Universitas Aisyah Pringsewu yang terdiri dari Program Studi Psikologi dan Program Studi Akuntasi melakukan kolaborasi dalam pengabdian kepada masyarakat mengenai "Manajemen Krisis di Masa Pandemi".

\section{Metode}

Bahan yang digunakan dalam kegiatan pengabdian ke masyarakat adalah materi berupa powerpoint, laptop, dan koneksi internet. Metode yang dilakukan dalam pengabdian ini yaitu ceramah dan diskusi (webinar) secara online. Terdapat dua tahapan dalam kegiatan pengabdian ini yaitu:

1. Tahap Persiapan

Tahap persiapan kegiatan pengabdian meliputi:

a. Membuat poster webinar "Manajemen Krisis di Masa Pandemi".

b. Peserta webinar melakukan registrasi dengan mengisi data diri di link http:/bit.ly WebinarSosbis1

c. Persiapan ruangan yang kondusif untuk pembicara dan moderator webinar

2. Tahap Pelaksanaan Kegiatan

Pelaksanaan kegiatan pengabdian ini terdiri dari beberapa kegiatan antara lain:

a. Pembukaan yang dibuka oleh Dekan Fakultas Sosial dan Bisnis Universitas Aisyah Pringsewu

b. Perkenalan para pembicara webinar

c. Presentasi Pembicara 1 mengenai "Manajemen Finansial di Era New Normal"

d. Presentasi Pembicara 2 mengenai "Menjaga Kewarasan untuk Tetap Sehat Mental"

e. Melakukan tanya jawab dan diskusi

\section{Hasil dan Pembahasan}

Kegiatan pengabdian masyarakat yang berjudul "Manajemen Krisis di Masa Pandemi" telah dilaksanakan pada hari Kamis tanggal 2 Juli 2020 secara online.

1. Kondisi Masyarakat di Masa Pandemi

Kegiatan awal sebelum melaksanakan webinar ini diawali dengan melakukan identifikasi masalah. Hal tersebut bertujuan untuk memperoleh informasi terkait dengan kondisi masyarakat di masa pandemi yang menjadi topik pembicaraan dalam webinar. Teknik yang dilakukan untuk mengidentifikasi masalah melalui survey kepada peserta webinar.

Berdasarkan hasil survey yang dilakukan oleh tim pengabdian masyarakat terhadap peserta webinar didapatlan masalah-masalah yang dirasakan oleh peserta webinar antara lain merasa bosan di rumah, khawatir, berkurangnya pendapatan atau finansial, kesulitan bersosialisasi dengan teman, khawatir dalam melakukan perjalanan kerja, khawatir sulit memahami materi kuliah online, dan jenuh dengan work from home.

Dengan berbagai permasalahan tersebut menjadi alasan peserta untuk mengikuti kegiatan webinar "Manajemen Krisis di Masa Pandemi" yang bertujuan untuk memberikan edukasi kepada 
masyarakat bagaimana melakukan manajemen diri baik secara finansial maupun psikologis di masa pandemic COVID-19.

2. Manajemen Finansial di Masa Pandemi

Pada masa pandemik ini membuat seluruh kehidupan kita berubah, tidak hanya kesehatan yang harus diperhatikan tetapi masalah keuangan juga berdampak dengan adanya pandemik ini. Dan kita dituntut untuk beradaptaasi dengan cepat sambil memikirkan bagaimana menghadapi krisis khususnya dalam finansial. Manajemen keuangan menjadi hal krusial bagi setiap orang untuk tetap bisa bertahan dalam masa pandemik ini, atau bahkan bisa menjadi lahan profit. Maka walaupun kondisi pandemik jangan lah kita meratapi atau mengeluh dengan keadaan. Karena hal tersebut tidak akan membuat perubahan dalam hidup kita.jadi kita harus tetap semangat dan berpikir kritis untuk bisa mendapatkan pemasukan di masa pandemik ini, dan disini adalah moment yang membuat kita tidak patah semangat dan berfikir kreatif.Terdapat beberapa cara stategi dalam mengelola keuangan selama pandemik COVID-19 antara lain :

a. Melakukan dagang

Jaman ini semua dituntut serba cepat dan praktis.terlebih lagi pada masa pandemik yang namanya online, jadi hal yang digemari oleh masyarakat.Protokol kesehatan yang membuat orang-orang harus menjalankan Physical dan social distancing, menjadi peluang utama terbentuknya usaha online

Besarnya jumlah penduduk dan kebutuhan akan pemenuhan kebutuhan sehari-hari, terselamatkan oleh aplikasi belanja online. Mulai dari antar jemput makanan, dan minuman, benaja kebutuhan sehari-hari.

Peluang usaha online ini menjadi salah satu cara untuk mendulang uang, sekaligus mengurangi resiko penyebaran Covid-19. Berdagang secara online tidak harus membuat brand atau produk sendiri. Banyak juga yang memanfaatkan stategi jurus reseller

b. Sulap hobi kamu menjadi uang

Paling enak dan menyenangkan adalah hobi yang dibayar. Dengan memanfaatkan potensi kreatifitas dan sumber daya yang kita miliki, maka peluang mendulang profit akan semakin besar.

Contohnya bagi yang suka memasak, maka bisa menjadikan hobi masaknya untuk dibuat usaha kuliner berbasis daring.ada juga yang suka dengan aktivitas tanam-menanam dengan media hidroponik, bisa dijadikan peluang untuk usaha instanlasi perkebunan hidroponik mini dirumah, ada juga membuat masker dengan gambar sendiri, dan sebagainya
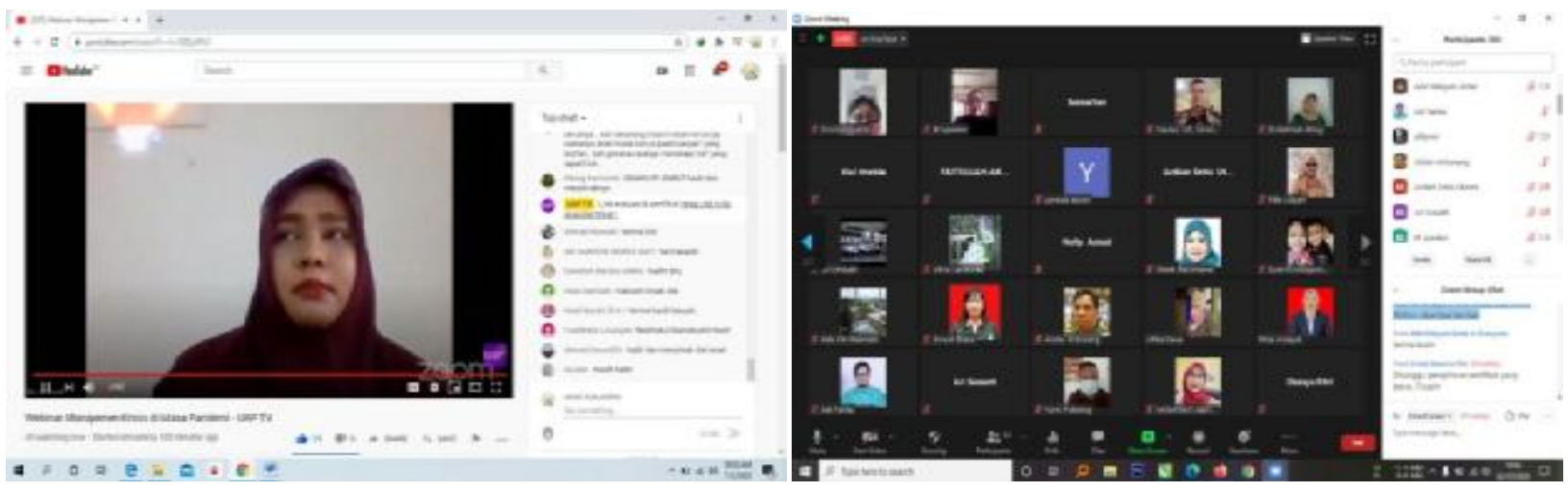

3. Manajemen Kesehatan Mental di Masa Pandemi

Masa pandemik COVID-19 menimbulkan banyaknya perubahan kehidupan yang harus dihadapi masyarakat. Perubahan-perubahan tersebut antara lain perubahan pola kerja di rumah, belajar di rumah bagi anak-anak, adanya aturan untuk melakukan physical distancing dan perlunya mematuhi protokol kesehatan berupa menggunakan masker, rutin mencuci tangan dan sebagainya. 
Selain perubahan kehidupan, masa pandemik COVID-19 juga mengancam masyarakat. Ancamanancaman yang dihadapi masyarakat selama pandemic COVID-19 berupa keadaan yang tidak pasti yang mana belum tahu kapan pandemi berakhir dan kemungkinan bisa tertular virus dimana saja tanpa disadari serta ancaman finansial (Prime, Wade, \& Browne, 2020).

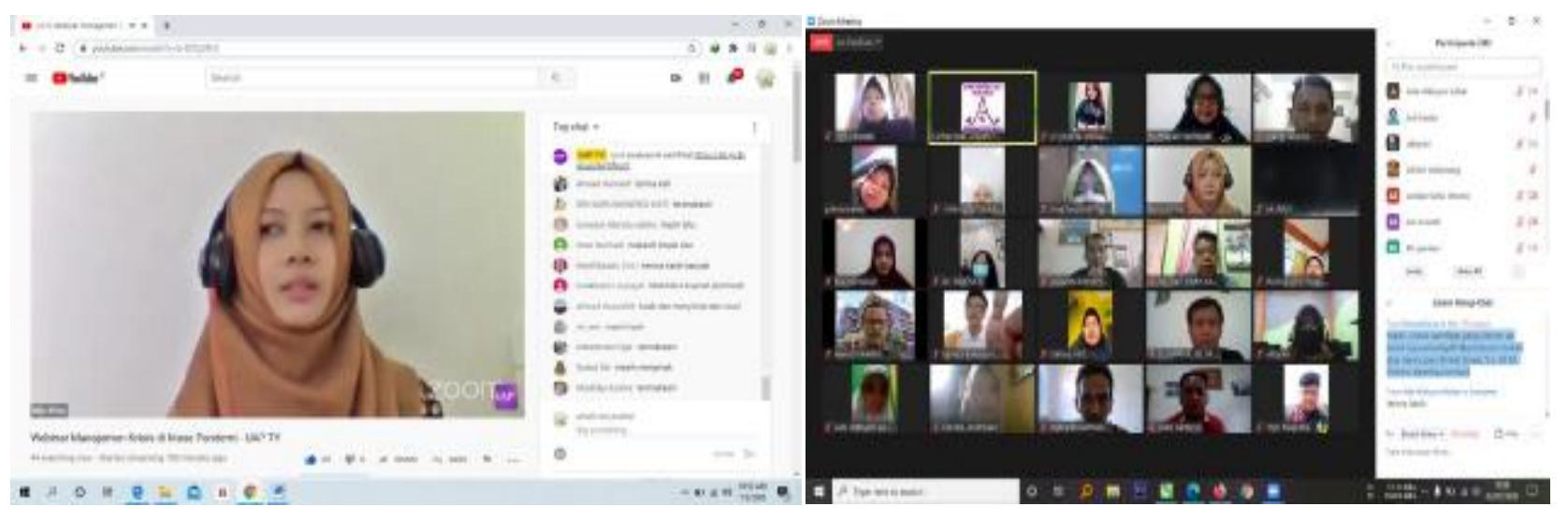

Dampak-dampak pandemik COVID-19 tersebut menimbulkan permasalahan psikologis antara lain ketakutan, kecemasan, stress, depresi, kesepian, kebosanan dan cabin fever. Terdapat beberapa cara untuk dapat mengatasi permasalahan psikologis di masa pandemik antara lain:

a. Melakukan "Self Care"

Untuk melakukan self care, terdapat beberapa cara antara lain tidur berkualitas, makan makanan yang bergizi, olahraga (melakukan peregangan, jogging dan lainnya), tetap terhubung dengan keluarga dan teman via online, membatasi seberapa banyak waktu untuk melihat gadget, menggunakan sosial media untuk hal-hal positif, dan membantu orang lain.

b. Melakukan Strategi Koping

Terdapat beberapa cara untuk melakukan coping antara lain:

1. Aktivasi Perilaku

Melakukan berbagai aktivitas termasuk hobi misalnya membaca, mendengarkan musik, bermain instrument musik, belajar bahasa, belajar masak, berkebun dan menyiapkan atau merencanakan bagaimana kehidupan dapat meningkatkan ksejahteraan psikologis selama masa pandemik.

2. Koping Penerimaan

Koping berbasis penerimaan mencakup bagaimana seseorang menghadapi respons seperti ketakutan dan kekhawatiran yang dikarenakan adanya sumber stress atau sesuatu peristiwa yang tidak terkendali tanpa menghakimi kondisi internal yang muncul sebagai respons terhadap stres (misalnya, ketakutan, keraguan, menyalahkan diri sendiri) dengan cara penerimaan. Dalam penerimaan bukan untuk berusaha mengubah, mengalihkan perhatian, atau mengalihkan diri dari ketakutan, kecemasan dan sebagainya. Terdapat alasan yang baik untuk takut akan virus, karena hal itu adalah potensi kematian, akan tetapi rasa takut tidak perlu mendominasi kehidupan seseorang. Disarankan untuk hidup berdampingan dengan ketakutan yang realistis untuk menghadapi respon secara adaptif.

3. Latihan Cinta-Kasih

Latihan cinta kasih adalah alat yang berguna selama pandemi COVID-19 karena mempromosikan interaksi dan membangun resilensi (kemampuan individu untuk bangkit kembali) dengan menumbuhkan emosi positif dan sosial koneksi, meningkatkan motivasi untuk mengakses dan menyediakan dukungan sosial, dan melahirkan perilaku prososial (Leiberg, Klimecki \& Singer, 2011). Latihan cinta kasih dilakukan dengan membangun selfcompassion. Self-compassion dikonseptualisasikan sebagai bentuk adaptasi dari relasi diri yang melibatkan tiga hal, yaitu menumbuhkan kesadaran terhadap penderitaan 
seseorang, memperlakukan diri sendiri dengan baik di masa-masa sulit dengan penuh pemahaman, serta menghubungkan pengalaman stres seseorang ke perspektif yang lebih luas dari pengalaman manusia.

4. Koping Religius

Menjadikan ibadah sehari-hari seperti berdoa, dzikir dan lainnya menjadi lebih bermakna bukan sekedar rutinitas kewajiban untuk mendapatkan ketenangan jiwa.

c. Mencari bantuan professional

Beberapa praktisi seperti psikolog, psikiater, pekerja sosial dan lainnya mengembangkan inisiatif untuk membantu meningkatkan permasalahan psikologis dan kondisi lainnya dengan melakukan pelayanan secara online melalui WhatsApp, Meets, Zoom, dan platform lainnya. Masyarakat dapat mengakses layanan kesehatan mental melalui WhatsApp, Meets, Zoom, dan platform lainnya selama masa pandemik.

4. Pelaksanaan Kegiatan Pengabdian

Kegiatan pengabdian ini dilaksanakan pada hari Kamis, tanggal 2 Juli 2020. Kegiatan dilaksanakan secara online. Rundown kegiatan pengabdian dapat dilihat pada tabel 1 di bawah ini:

\begin{tabular}{ll}
\hline \multicolumn{1}{c}{ Waktu } & \multicolumn{1}{c}{ Kegiatan } \\
\hline $09.00-09.15$ & Pembukaan Kegiatan oleh Dekan Fakultas Sosial dan Bisnis \\
\hline $09.15-09.30$ & Perserta webinar mengisi survey kondisi selama pandemi \\
\hline $09.30-10.00$ & $\begin{array}{l}\text { Penyampaian materi oleh Pembicara 1 mengenai "Manajemen Finansial di } \\
\text { Era New Normal” }\end{array}$ \\
\hline $10.00-10.30$ & $\begin{array}{l}\text { Penyampaian materi oleh Pembicara 2 mengenai "Menjaga Kewarasan untuk } \\
\text { Tetap Sehat Mental” }\end{array}$ \\
\hline $10.30-11.00$ & Melakukan sesi tanya jawab dan diskusi \\
\hline
\end{tabular}

5. Evaluasi

Dilakukan tanya jawab dan diskusi kepada peserta webinar mengenai serangkaian kegiatan yang telah dilaksanakan untuk mengetahui seberapa jauh perserta webinar memperoleh pemahaman tentang manajemen krisis selama masa pandemik.

\section{Kesimpulan}

Dengan dilakukannya pengabdian kepada masyarakat secara online mengenai manajemen krisis selama masa pandemi, perserta webinar dapat memperoleh informasi dan menerapkan manajemen finansial dan manajemen kesehatan mental dalam masa pandemi COVID-19 agar memperoleh kesejahteraan.

\section{Ucapan Terimakasih}

Ucapan terima kasih terutama ditujukan kepada LPPM Universitas Aisyah Pringsewu yang telah memberikan izin untuk keberlangsungan pengabdian kepada masyarakat. 


\section{Daftar Pustaka}

Astuti, M., Ritonga, M., Irviani, R., Mukhlis, H., \& Chauhan, R. (2020). Developing Regional Autonomy: Lesson Learned from Norway. European Journal of Molecular E Clinical Medicine, 7(02), 2020.

Dubey, S., Biswas, P., Ghosh, R., Chatterjee, S., Dubey, M. J., Chatterjee, S., ... Lavie, C. J. (2020). Psychosocial impact of COVID-19. Diabetes \& Metabolic Syndrome: Clinical Research $\mathcal{E}$ Reviews. https://doi.org https://doi.org/10.1016 h.dsx.2020.05.035

Kaustav, C., \& Moumita, C. (2020). Psychological impact of COVID-19 pandemic on general population in West Bengal: A cross-sectional study. Indian Journal Psychiatry, 62(3), 266-272. https://doi.org/10.4103/psychiatry.IndianJPsychiatry_276_20

Harlianty, R. A., \& Paramastri, I. (2020). The role of religious coping as a moderator of the relationship between psychological burden and quality of life among caregiver of women with breast cancer. Journal of Psychological Perspective, 2(2), 71-78.

Harlianty, R. A., Widyastuti, T., Mukhlis, H., \& Susanti, S. (2020). Study on awareness of COVID-19, anxiety and compliance on social distancing in Indonesia during Coronavirus Disease 2019 (COVID-19) pandemic.

Laing, T. (2020). The economic impact of the Coronavirus 2019 (Covid-2019): Implications for the mining industry. The Extractive Industries and Society. https://doi.org https://doi.org/10.1016/.exis.2020.04.003

Leiberg, S., Klimecki, O., \& Singer, T. (2011). Short-term compassion training increases prosocial behavior in a newly developed prosocial game. PloS one, 6(3), e17798. https://doi.org/10.1371 journal.pone.0017798

Muarif, A. K., \& Adiyanti, M. G. (2020). Pengaruh pelatihan emotional intelligence terhadap burnout pada petugas kepolisian. Journal of Psychological Perspective, 2(1), 13-24.

Mukhlis, H. (2015). Pelatihan kebersyukuran untuk menurunkan kecemasan menghadapi ujian nasional pada siswa SMA. Gadjah Mada Journal of Professional Psychology (GamaJPP), 1(3).

Mukhlis, H., Kristianingsih, A., Fitrianti, F., Pribadi, T., Kumalasari, D., Febriyanti, H., \& Maseleno, A. (2020). The effect of expressive writing technique to stress level decrease of new student at Al-Falah Putri Islamic Boarding School, Margodadi, Tanggamus. Annals of Tropical Medicine and Health, 23, 192-200.

Prime, H., Wade, M., \& Browne, D. T. (2020). Risk and resilience in family well-being during the COVID19 pandemic. American Psychologist, 75(5), 631-643. http://dx.doi.org/10.1037/amp0000660

Truman, B. I., Tinker, T., Vaughan, E., Kapella, B. K., Brenden, M., Woznica, C. V, ... Lichtveld, M. (2009). Pandemic influenza preparedness and response among immigrants and refugees. American Journal of Public Health, 99 Suppl 2(Suppl 2), S278-86. https://doi.org/10.2105/AJPH.2008.154054

Temsah, M.-H., Al-Sohime, F., Alamro, N., Al-Eyadhy, A., Al-Hasan, K., Jamal, A., ... Somily, A. M. (2020). The psychological impact of COVID-19 pandemic on health care workers in a MERS-CoV endemic country. Journal of Infection and Public Health. https://doi.org https://doi.org/10.1016/j.jiph.2020.05.021

Yuliaty, F., Purnama, Y., Akbar, F. M., Mukhlis, H., \& Irviani, R. (2020). Behavioristic Psychology of the Modern Constitution. Journal of Critical Reviews, 7(8), 2019-2023.

WHO. (2020). Coronavirus disease (Covid-19). Diakses di https:/www.who.int/indonesia/news/novelcoronavirus 